\title{
Prescriptive Water Rights in California: Is Application a Prerequisite?
}

\author{
Russell R. Kletzing*
}

Prescription is one of the oldest methods of acquiring an interest in Preal property whether land or water. In California, however, since the passage of the Water Commission Act, there is some doubt as to the continuing validity of the old prescriptive rule as to the acquisition of water rights. The Water Commission Act requires that its provisions be followed to acquire a new water right. This means filing an application and completing the lengthy process required to obtain a license from the Division of Water Resources.

There is now some question whether a prescriptive right can be acquired without following the application procedure which the Water Commission Act set up. Many otherwise valid prescriptive rights have been acquired since 1913, the date of the Act. A determination of the validity of this type of prescriptive right, acquired without the benefit of an application to the Division, is therefore an important question for many water users.

In California the question whether an application to the Division of Water Resources is a prerequisite to obtaining a prescriptive right has never been squarely decided. At least one case has indicated that it is. A literal reading of some sections of the Water Commission Act leads to the same conclusion. Furthermore, the courts in some other states with similar laws have raised questions as to the validity of prescriptive rights gained without following the statutory procedure. On the other hand the overwhelming majority of the California cases assume that the application procedure is not necessary. They evaluate prescriptive rights with no reference to the statutory prerequisites. These cases represent tacit authority for the view that a prescriptive water right may be acquired without reference to statutory provisions.

One of those who has cast doubt upon the validity of prescriptive rights not fortified by adherence to the required statutory procedure is $\mathrm{Mr}$. Hutchins in his book, Selected Problems in the Law of Water Rights in the West. He discusses the entire problem. ${ }^{1}$ Cases in Utah, New Mexico, and Wyoming have held open the question of acquiring water rights by prescription alone. They suggest that such rights are of doubtful validity. In Utah, ${ }^{12}$ the legislature endeavored specifically to outlaw water rights acquired in other than the statutory manner.

Mr. Hutchins echoes the doubts of the state courts. He enumerates conditions under which he believes they may invalidate prescriptive rights. There will be a return to the discussion of Hutchins later, but it is enough

*Attorney, Bureau of Reclamation Regional Office, Sacramento.

1 Hutchuns, Selected Problems iv tele Law of Water Rigits iv the West 400 (1942).

1a Utah Laws 1939, c. 111. 
for now to note that the laws in Utah and the other states are quite similar to California's Water Commission Act.

The Water Commission Act ${ }^{2}$ of California was enacted in 1913. In common with the similar acts of other western states, it prescribes what purports to be an exclusive method to acquire water rights. It is the feature of exclusiveness which gives rise to doubts concerning water rights gained by other means such as prescription.

The section of the Water Commission Act indicating the exclusiveness of the administrative procedure is now codified as Water Code Section 1225. It reads:

No right to appropriate or use water subject to appropriation shall be initiated or acquired except upon compliance with the provisions of this division.

It is reinforced by Section 1052 as follows:

The diversion or use of water subject to the provisions of this division other than as authorized in this division is a trespass, and the department may institute in the superior court in and for any county wherein such diversion or use is attempted appropriate action to have such trespass enjoined.

Reading these sections literally, they appear to set up an exclusive method for the acquisition of water rights. Neither section has ever been discussed in cases of prescription. It might be argued that the scope of these sections is limited. Section 1225 applies to "water subject to appropriation" and Section 1052 to "water subject to the provisions of this division." It is not worth while to pursue this argument to its logical extreme. The apparent intent is to establish an exclusive procedure.

The California case of Crane v. Stevinson ${ }^{3}$ takes the Water Commission Act at face value. The court says:

Since the effective date (year 1913) of the Water Commission Act, an intending appropriator has been required to file his application with the water commission (now the division of water resources). This the plaintiff did not do. To sustain his claim, the appropriation made by hinı must have been actually complete at some time prior to said 1913 date, and even that is not sufficient if the evidence shows a subsequent failure to maintain the beneficial use for the period of time prescribed by the statute, or for the period of time, five years, required under decisions prior to the statute.

The reasoning is that since plaintiff did not comply with the requirenuents of the Water Commission Act, he could have acquired no prescriptive right after its effective date. The only way he could demonstrate such a right would be to prove that he had fulfilled the requirements for prescription before the act became effective.

This quotation is the only part of the opmion pertinent to the subject of prescription and the Water Commission Act. The court did not discuss the question of the necessity of making an application in order to gain prescriptive rights. It assumed the necessity. This case, together with the literal statements in the Water Code and the views which Hutchins expresses

2 Cal. Stats. 1913, p. 1012.

35 Cal.2d 387, 398, 54 P.2d 1100, 1105-1106 (1936). 
in his textbook, is the only authority indicating that prescriptive rights gained without sanction of the Division of Water Resources may not be valid. Crane v. Stevinson is a holding in that direction, but a holding without discussion and without meeting the objections to such a rule.

The Water Code sections already discussed make reasonably clear that water rights can only be gained by complying with the provisions concerning applications. If a prescriptive right can nevertheless be gained without going through the admimistrative process it is necessary to develop a basis for exception. Fortunately, this has already been done by Mr. Samuel C. Wiel in his article, Unregistered Water Appropriations at Law and in Equity. ${ }^{4} \mathrm{It}$ is impossible to overstate the value of this article. Nothing can replace a reading of it, but a summary will be included at this point.

Mr. Wiel discusses cases in Wyoming and Utah which held no water right can be acquired except through the administrative processes. A federal court applying Wyoming law and the Idaho Supreme Court took the other view. To elucidate the problem these cases present, Wiel delves into the question of making exceptions to clear statutory prohibitions. There are in this case two interests to be considered-that of the conflicting claimants, or private interest; also the interest of the state, or public interest. First is the discussion of the private interests.

The Statute of Frauds and the Statute of Enrollments have clear statutory language which has been modified by equity. Equity relieves against these statutes not only to prevent actual fraud but also to protect the innocent party who relies upon appearances. Although under the Statute of Enrollments, or now under the recording acts, the record is to govern title, equity nevertheless protects the innocent purchaser as against the grantee who takes with notice. Also, in a Statute of Frauds situation justified reliance, as in the case of part performance, will serve to take a case out of the clear mandate of the statute or will require equity to create a constructive trust.

The application procedure for establishing titles to water rights is closely analogous to the requirements of the recording acts and the Statute of Frauds. Almost identical language has been used in demonstrating the desirability of the certainty of title which these acts try to achieve. Continuing the analogy, the appropriator with no permit is in the position of one in possession of land and his possession gives notice to the would-be applicant for water rights. Equity clearly would not countenance the claim of the fraudulent permittee, as, for instance, the agent who fraudulently acquires a permit in his own name instead of in that of his principal. On the same basis, equity will make an exception to the statute where the applicant-permittee has notice of the existing appropriation.

To quote some of Wiel's own words:

It is a corollary that when a person is visibly in possession of property it is notice; and possession of ditches and a water system is possession of the water right so far as the intangible nature of that right will permit.

\footnotetext{
414 CALIF. L. Rev. 427 (1926).
}

- Id. at $431-434$. 
"But where one has actually diverted water, and is using it, the right to its use may, by analogy, be likened unto the doctrine that one purchasing real estate must take notice of the rights of those in possession, notwithstanding the recording statutes. Water diverted from a stream naturally diminishes the volume. One seeking to acquire the right to the use of water must take notice of the amount available and visible, and it must be conclusively presumed that he inquires into the extent of the supply from which the water is to be drawn, and how that supply has been diminished by others whose rights are prior in time." ...

Writing, recording, surveying, and every other precaution have to give way to possession at times. The Wyoming-Utah rule recognizes this so far as the record cannot be perfect and must fail when the controversy is between two claimants neither of whom has a permit. Many other cases also must lie in parol, as estoppels, prescriptions, and the like. If paper invariably controlled over possession "the confusion of lines and titles that would follow would cause consternation in many communities. Indeed, the mischiefs that must follow would be simply incalculable, and the visitation of the surveyor might well be set down as a great public calamity." ...

The Water Codes' assumption of absolutism of a record as a panacea for titles, as also in the very similar Torrens Acts for land, represents the recurrent belief in ritual as the sure road to individual happiness, almost ecclesiastical in its hardness. It is always tempted to go to harsh extremes, for a beatitude beyond reach.

... It seems, therefore, that there is no distinction from other recording acts so far as private interests are the consideration, and no reason why the equity doctrine of notice should be less applicable under the permit acts; and the Supreme Court of Idaho has, by a line of precedents, established for Idaho that it is applicable.

Illustrating Wiel's point of view in a general way are two Interior Department decisions. They hold the actual appropriator may prevail over the prior permittee. ${ }^{6}$

Wiel's article deals in terms of the general principle of acquiring any appropriative right without conformity to the statutory procedures. An obvious application of the general theory is in the case of prescription. Prescription is an exception to the recording acts. On the same basis it must be an exception to the Water Commission Act. In either case, the illusion of impeccable paper titles must yield to the reality of open and notorious possession.

So much for the private interests. The public interest must be considered separately. Equity will not derogate the interest of the state even to protect an innocent party. In a dispute over water rights between private parties equity need not take cognizance of the interest of the state unless the state appears in the action to present it. However, this has ordimarily not been the case. It was not the case in the Wyoming and Utah suits,

6 Anderson v. Spencer, 38 Land Dec. Rep. 338 (1909) ; De Weese v. Henry Inv. Co., 39 Land Dec. Rep. 27 (1910).

7 But cf. State v. Dority, 225 P.2d 1007 (N. M. 1950). 
already discussed, which Wiel cites. Especially it has not been the case in any California suit involving prescriptive rights.

It is not justified to say that the claimant attacking the prescriptive right of a non-applicant is acting on behalf of the state. Unless the state intervenes, its interests cannot properly be considered as between the parties. If it does seek to enjoin the unauthorized diversion as a trespass it is unjust to allow state action to inure to the benefit of another party. The probable result of such a suit would be that equity would decree a retroactive permit on behalf of the negligent appropriator.

Thus Mr. Wiel's argument is complete. Both private and public interests have been assuaged. The course of justice lies in protecting the innocent party and creating an exception to the statute. For the same reasons as those underlying prescriptive titles to land, prescriptive water rights should be made an exception to the statutory method of appropriation.

With the background of Mr. Wiel's article, it is possible to evaluate Mr. Hutchins' contribution to the law of prescriptive water rights. The difficulty in his approach is at once apparent. Hutchins considers that such matters as the statement in the statute as to the exclusiveness of the statutory procedure, provision as to forfeiture through illegal use of a water right, or the provision as to whether a water right may be detached from the land to which it is appurtenant, will control the case. He shows no recognition of the possibility of a general equitable exception to these peremptory statutes in favor of the innocent party. His failure to grasp the situation is shown by the section of his book immediately following his discussion of prescriptive rights in which he collects authorities demonstrating that water rights may change hands by operation of an estoppel. ${ }^{72}$ The principle underlying the exception to the "exclusive" provisions of the statute in the case of estoppel is, of course, the same as that on which the prescriptive exception is based.

Mr. Wiel's discussion furnishes a basis in logic and history for subjecting a clear mandate of the statute to the equitable requirement of fairness. In the particular case, prescription should be an exception to the Water Commission Act as it is to the recording act. However, Wiel does not favor the reader with citations to any cases directly sustaining his viewpoint, much less any California cases. It remams to see if the California cases have followed his inexorable logic.

It is easy to understand why Mr. Wiel had no cases to cite discussing the equitable exceptions to the Water Commission Act. Were he writing today he would be no better off. None of the California cases on prescriptive water rights discusses that point. None discusses even whether or not the act applies to prescription. Except in Crane v. Stevinson, all the cases on prescription implicitly assuine that no requirement of the Water Commission Act need be met.

Before 1913, when the Water Commission Act came into being, Civil Code Section 1415 provided a system for acquiring water rights by posting

in Hutchons, op. cit. supro note 1 , at 402 . 
and recording notices. The cases have made clear that this method was not exclusive. In Antioch v. Williams Irr. Dist., ${ }^{8}$ the court says:

The fact that the city has never posted a notice of appropriation, as provided in section 1415 of the Civil Code, is likewise immaterial. "Where there has been actual appropriation of water, a right to it is acquired, without following the course laid down in the code."

Civil Code Section 1415 was supplanted by provisions of the Water Commission Act relating to applications and permits. As has already been pointed out, Water Code Section 1225 purports to make these new provisions exclusive. In relation to prescription, it is subject to attack by virtue of the limitation of scope which it contains. In addition the California Supreme Court has twice seen fit, in mcidental discussions, to limit its application. ${ }^{10}$ The Tulare Water Co. v. State Water Com. opinion recites:10a

Under the law in force prior to the adoption of this act (Civ. Code, $\$ \$ 1410-1422)$ no permission was required for the appropriation of waters of the state. All that was required to create a preferential right to such water was to actually appropriate it to some authorized beneficial use, or to make a water filing to be followed with due diligence by an actual user.

The obvious aim of the Water Commission Act was not to abolish, but to regulate and administer this privilege.

Elsewhere it has been said that appropriation is but a form of prescription and that appropriative water rights are gained against other users only by prescription. $^{11}$

The array of material substantiating the view that a prescriptive right can be acquired without an application to appropriate unappropriated water does not stop with the ambiguous statements of the courts as to the exclusiveness of the Water Commission Act. Holdings and dicta in a large number of cases decided since 1913 are susceptible of the inference that prescription by itself can give rights to water. Two California cases make direct holdings, although without discussion, that no application is necessary.

Seneca C. G. M. Co. v. Gt. Western Power Co. ${ }^{12}$ dealt with a prescriptive right of the power conipany through operation of a dam at Lake Almanor on the Feather River. The court held that a prescriptive right to store water had been acquired against the lower riparian owners. The dam was built in 1913 so the prescriptive period occurred after the passage of the Water Commission Act. No application has ever been made to the Water

\footnotetext{
8188 Cal. 451, 456, 205 Pac. 688, 691 (1922).

9 See also the cited cases immediately following the quoted passage, especially De Necochea v. Curtis, 80 Cal. 397, 20 Pac. 563, 22 Pac. 198 (1889).

10 Tulare Water Co. v. State Water Comm., 137 Cal. 533, 536, 202 Pac. 874, 876 (1921); Yuba River Power Co. v. Nevada Irr. Dist., 207 Cal. 521, 526, 279 Pac. 128, 130 (1929). $10 a$ Supra note 10 at 536,202 Pac. at 876.

11 San Bernardino v. Riverside, 186 Cal. 7, 13, 14, 198 Pac. 784, 787 (1921); address of Chief Justice Shaw before the American and the California Bar Associations, 189 Cal, 779, 792 (August 9, 1922).

12209 Cal. 206, 287 Pac. 93 (1930).
} 
Commission for storage at Lake Almanor by the Great Western Power Company or its successor, Pacific Gas and Electric Company. The court in sustaiining the prescriptive right in effect held that it was not necessary to show an application to appropriate unappropriated waters to establish such a right. In Moore v. California-Oregon Power $\mathrm{Co} .{ }^{13}$ the court upheld the company's prescriptive right to store water at night. This dam was built in 1917. There was not enough information in the opinion to check the records for an application to the Water Commission. The court made no mention of an application.

In several cases the Califorma Supreme Court has made carefully considered statements enumeratimg the requirements for prescription. An application to appropriate unappropriated water was not imcluded in any of thein. One of these is made in the celebrated case of San Diego v. Cuyamaca: ${ }^{14}$

The nature of the right claimed to have been acquired in the waters of a flowing stream by prescription rests as a prime essential upon an adverse use thereof by the claimant under a claim of right which has, to the extent thereof and for the required term of years, been acquiesced in by the person or persons otherwise entitled to the ownership and enjoyment of the waters thus adversely abstracted from said stream and to enforce these rights by appropriate action. It is needless to cite authorities to a proposition thus deeply grounded in the law of waters. ${ }^{15}$

Although the requirements for prescription are discussed in considerable detail in these cases no mention is inade in any of them of the necessity for an application to the Division of Water Resources.

Some further imference that an application to appropriate unappropriated water is not necessary to a prescriptive water riglit may be drawn from another group of cases. ${ }^{16}$ They were decided in the period after the

\footnotetext{
1322 Cal.2d 725, 140 P.2d 798 (1943).

14 278 Pac. 840, 848 (1929), aff'd, 209 Cal. 105, 287 Pac. 475 (1930).

15 Another such statement is contained in Big Rock M. W. Co. v. Valyermo Ranch Co, 78 Cal. App. 266, 273, 248 Pac. 264, 267 (1926), as follows:

"In general it may be said that a permanent right to the use of the water or a water right may be acquired in the western states by one who has complied with the essential elements for the statutory period which constitute the adverse user of the water amounting to prescription. This right may be acquired as against one who formerly claimed the water by virtue of a prior appropriation, as a riparian owner, as a purchaser, or as against one who originally claimed the right to the water by prescription itself, or as against one who had acquired the right to the water by any other method. It follows that the rights of an appropriator may be lost in whole or in part by the adverse possession and the user of the water by another amounting to prescription. Where one has complied with all the essentials necessary and has had the continued, open, notorious, exclusive, uninterrupted, and adverse use and enjoyment of the water under a claim of right for at least the period of time prescribed by the statute of the state where the right is claimed for the commencement of actions for recovery of real property, the law will presume a grant of the right so held and enjoyed."

See also Bloss v. Rahilly, 16 Cal.2d 70, 78, 104 P.2d 1049, 1053 (1940).

16 Joerger v. Pacific Gas \& Electric Co, 207 Cal. 8, 24, 276 Pac. 1017, 1025 (1929); Barr v. Ream, 216 Cal. 248, 13 P.2d 920 (1932); Morgan v. Walker, 217 Cal. 607, 20 P.2d 660 (1933); Larsen v. Apollomo, 5 Cal.2d 440, 55 P.2d 196 (1936); Witherill v. Brehm, 74 Cal. App. 286, 240 Pac. 529, 532 (1925) ; Mt. Shasta Power Corp. v. McArthur, 109 Cal. App. 171, 292 Pac. 549 (1930); Fruit Co. v. Sweetwater W. Corp., 7 Cal. App.2d 490, 45 P.2d 1031 (1935).
} 
Water Commission Act. All involved a claim to a prescriptive right for the use of water. The prescriptive periods either occurred before 1913 or were not sufficiently identified in the opinions to tell when the claimed adverse use had taken place. Clearly, no compliance with the statutory procedure was necessary to the prescriptive rights claimed in these cases. ${ }^{17}$ Their value lies in the fact that the court did not differentiate them from cases arising after the Water Commission Act. Although the Act was in effect at the time of their decision, no reference was made to it in any of the opinions.

A much stronger inference may be drawn from a group of cases in which the prescriptive period occurred after $1913 .{ }^{18}$ Prescriptive rights were either upheld or denied. None of the opinions mentioned the requirement for complying with the Water Commission Act. Apparently the courts assumed that compliance is not necessary in the case of prescription.

The very recent case of Pasadena $v$. Alhambra ${ }^{10}$ deserves mention here only to be distinguished. In it the court sustained a large number of prescriptive rights to percolating groundwater. This holding has no significance for our discussion. Water Code Section 1201, at least prima facie, limits the scope of the appropriation Division of the Code to "water flowing in any natural channel."

\section{CONCLUSIONS}

A large number of cases mvolving prescriptive rights to the use of water have been decided since 1913, the date of the Water Commission Act. In all of these except Crane v. Stevinson, the decisions have implicitly assumed that the act was not applicable. No application to appropriate unappropriated water seems necessary as a prerequisite to a prescriptive right. The proposition, however, has never been made explicit. The courts never discussed the applicability of the Water Commission Act.

On principle, the approach of the California courts is the correct one. As prescription of land has been excepted from the recording acts, so the prescription of rights to water should be outside the analogous laws. The same reasons, the prevention of deception of the innocent party relying on long-continued possession, are applicable in both cases.

Because the assumption of the California courts that prescriptive water rights were outside the statutory procedure has always been unexpressed, there is little to prevent a change from that position in the future. No cases would have to be overruled; at most, a few dicta would have to be discounted. There is no reason to believe that such a change will occur. Until it does, the water lawyer must work on the basis of the courts' assumption that a prescriptive right may be gained without applying to the Division of Water Resources.

17 Antioch v. Williams Irr. Dist., supra note 8.

18 Scott v. Fruit Growers Supply Co., 202 Cal. 47, 258 Pac. 1095 (1927); Bazet v. Nugget Bar Placers, Inc., 211 Cal. 607, 296 Pac. 616 (1931); Crum v. Mt. Shasta Power Corp., 117 Cal. App. 586, 4 P.2d 564 (1931); Crain v. Hoefling, 56 Cal. App. 2d 396, 132 P.2d 882 (1942); Elliott v. Bertsch, 59 Cal. App. 2d 543, 139 P.2d 332 (1943).

1033 Cal.2d 908, 207 P.2d 17 (1949). 